\title{
In memoriam Prof. F.J. Stevenson and the Question of humic substances in soil
}

\author{
Alessandro Piccolo*
}

In early January 1978, I landed on the Urbana-Champaign airfield as the first snowflakes of one of the coldest ever winters of the US Midwest just began to stick to the ground. Prof. F.J. Stevenson was there to kindly pick me up and to begin for me the precious chaperon role that he played during my year-long Fulbright-Hays-sponsored scientific association with the University of Illinois at Urbana-Champaign. Now that Frank Stevenson passed away on May 29th, 2015 at the age of 93, I feel that I should pay a public tribute to the scientist and to the man. When I began to work in his laboratory as a young physical organic chemist from the University of Rome, Italy, Frank Stevenson had already been a Full Professor of Soil Chemistry for more than 15 years, and he was an established legend in the field of the organic chemistry of soil. He had already published his highly quoted Science paper on environmental nitrogen as well as several innovative and fundamental articles and book chapters on humus chemistry and organic geochemistry, including those on ammonium, amino acids, amino sugars, and metals in soil. My scientific acquaintance with him kindled my interest in the organic chemistry of soil and his competence, experience and serious scientific approach introduced me to the practical chemical techniques for use in investigations of the "mysterious" humic substances. He offered various research topics and I chose to work on the evaluation by infrared spectrometry of the type of bonds formed between metals and chelating humic functional groups. This decision was of mutual interest, since I could exploit my physical organic-chemical background and use the brand new infrared spectrometer that Frank Stevenson had just bought for his laboratory. The application of this technique to humus chemistry was then relatively new, and the complexity of humic matter and the overlapping of infrared bands conspired against the chance to obtain meaningful results.

\footnotetext{
*Correspondence: alessandro.piccolo@unina.it Università degli Studi di Napoli Federico II, Naples, Italy
}

I was frustrated at having to work with such complex, unidentified chemical material that was so very different from the pure and structurally known metal-organic molecules that I had previously been accustomed to. Frank was calm and encouraging in supporting my efforts. Finally, I was drawn out of the impasse by adopting a stepwise approach for the progressive metal complexation in terms of the percent of humic acidic functional groups. This led to a successful joint publication in Geoderma.

The understanding of Frank Stevenson of the nature of soil humic substances was anchored in the interpretation formed in the fifties by the Russian soil scientist, Prof. M.M. Kononova and expressed in her 1961 book "Soil Organic Matter". The poor analytical capability at the time, the apparent similarities of the characteristics of humus in different soil classes and the impact of the then modern biopolymer techniques which, Frank Stevenson had adapted for humic studies for the Ph.D. degree at Ohio State University, brought him and others who followed to view humic substances as high-molecular-weight polyelectrolytes synthesized de novo in soil [1]. However, the limitation of that view in terms of conformational structure, bioreactivity, and physical-chemical mobility in the soil solution prevented progression beyond a pure geochemical role for humic substances in soil and to appreciate the complex essential relationship between humic matter, soil microorganisms, and the below-ground plant roots activity.

The novel paradigm which I and my coworkers proposed in the late nineties gives much larger horizons to the environmental and ecological significance of humic matter. This has been based on evidence provided by the modern biochemical and advanced spectroscopic techniques, which describe humic substances as supramolecular structures $[2,3]$. This view has dismantled the previous macropolymeric concept, and it has given rise to the present day large consensus of soil humic molecules as degraded biomolecules of small molecular 
masses $(<1000 \mathrm{Da})$. These self-assemble in solution in metastable and heterogeneous suprastructures due to weak dispersive (van der Waals, $\pi-\pi$, and $\mathrm{CH}-\pi$ ) forces and hydrogen bonds. The concentration of humic suprastructures in the soil aqueous phase is in equilibrium with humic molecules in the solid phase, that are stabilized by either hydrophobic adsorption on the surface of aluminosilicates, or by specific sorption on iron and aluminum oxides, or by complexes with divalent and trivalent soil metals.

The accumulation of humic substances in soil (the so called "humification") is, therefore, a dynamic process, by which the heterogeneous byproducts of abiotic and biotic degradation of animal and plant tissues (lipids, peptides, oligosaccharides, etc.), are no longer covalently linked in implausible branched humic macropolymers of ever growing molecular masses. Instead, these are progressively protected from complete mineralization in weakly bound superstructures by the increasing concentration of hydrophobic components. These are thermodynamically excluded from water and, therefore, are no longer bioaccessible for mineralization. At the same time, this reservoir of "humic" molecules hydrophobically adsorbed on soil clay and chemically sorbed by oxides may again be released to the soil solution when exposed to conformational alterations due to root-exuded organic acids or to microbial degradation. This plant- and microbes-mediated equilibria between solid and liquid phases is the governing process of soil chemical and physical fertility. In fact, it provides the mobile "humic" molecules which play a bioactive role in plant growth, stabilize soil structure by forming organo-mineral complexes, and control the transport down the soil profile of organic matter and humic-bound contaminants.

The significance and the molecular implications in soil of the supramolecular theory of humic substances have been either insufficiently understood or simply ignored by some soil scientists. The growing scientific evidence that proved the supramolecular theory and the inconsistency of the traditional macropolymeric view, has recently [4] been turned into an oversimplification of the soil complex molecular dynamics by stating that the "persistence of soil organic carbon is primarily not a molecular property, but an ecosystem property"! Well-known general concepts of soil behavior and general chemical categories (solubility, molecular size, and functionalization) were again called upon, but were related to an ever ambiguous notation of "organic matter". These authors failed to appreciate that not only are the single soil molecular entities, at different stages of their biomolecular transformation, responsible for the interactions with soil inorganic particles and the selection of microbial communities, but also and more significantly, it is their suprastructural organization and their degree of hydrophobicity that controls processes of bio-accessibility and sorption and not vice versa. Most contemporary serious research findings are progressively pointing in that direction.

Although the concept of soil organic matter as a superstructure of self-assembling relatively small heterogeneous molecules appeared to be well apprehended by exponents of this group of soil scientists [5], they, nevertheless, radicalized their holistic view of an undefined organic matter in soil by flatly dumping the "humic substances" notation. It is surprising that such invocation is based only on the possible artifacts created by the traditional extraction of humus from soil, rather than onto a more objectively rationale thinking. In fact, there is no single piece of scientific work with sufficient molecular resolution (NMR spectroscopy cannot single out molecular structures in heterogeneous humic mixtures) that directly proves that what is extracted with the traditional alkaline solution does not correspond to molecules existing in soil. A detailed structural identification of molecules needs a preliminary extraction in a suitable medium and further purification before characterization. By the same token, one may discard the characterization of biomolecules so far isolated from cells, just because a particular kind of extraction was applied for their study (e.g., soil DNA), and the molecules may not be the same when inside cells as in the soil! Furthermore, the semantic ideology of these soil scientists when asking for the abandonment of the word "humus" is unclear and, above all, unsupported by a sound scientifically based alternative explanation of the chemical nature and reactivity of soil humic molecules. Their general description of soil processes may well be interesting to a large unprofessional audience, but somewhat confused to soil organic matter scientists. They substitute the commonly used term "humic substances" by a "soil continuum model" which is vague, devoid of chemical significance, and does not explain how this "continuum" would be molecularly arranged and thermodynamically protected from complete mineralization. Their scientific motivations for the iconoclastic refusal of the use traditional humic wordings do not appear to be objectively sufficient.

Obviously, I do not know what standpoint would my dear teacher and master, Frank Stevenson, take on this issue. I only know that his approach would be scientifically rigorous and intellectually honest, as all the endeavors he faced in his very respectable life.

\section{Competing interests \\ The author declares that he has no competing interests.}

Received: 29 May 2016 Accepted: 9 June 2016

Published online: 05 July 2016 


\section{References}

1. Stevenson FJ. Humates: facts and fantasies on their value as commercial soil amendments. Crops Soils Mag. 1979;31:14-6.

2. Piccolo A, Nardi S, Concheri G. Macromolecular changes of soil humic substances induced by interactions with organic acids. Eur J Soil Sci. 1996;47:319-28.

3. Piccolo A. The Supramolecular structure of humic substances. A novel understanding of humus chemistry and implications in soil Science. Adv Agron. 2002;75:57-134
4. Schmidt MWI, Torn MS, Abiven S, Dittmar T, Guggenberger G, Janssens IA, Kleber M, Kögel-Knabner I, Lehmann J, Manning DAC, Nannipieri P, Rasse DP, Weiner S, Trumbore SE. Persistence of soil organic matter as an ecosystem property. Nature. 2011;478(7367):49-56.

5. Lehmann J, Kleber M. The contentious nature of soil organic matter. Nature. 2015;528(7580):60-8.

\section{Submit your manuscript to a SpringerOpen ${ }^{\circ}$ journal and benefit from:}

- Convenient online submission

- Rigorous peer review

- Immediate publication on acceptance

- Open access: articles freely available online

- High visibility within the field

- Retaining the copyright to your article 